Arq. Bras. Med. Vet. Zootec., v.68, n.3, p.814-820, 2016

\title{
Influence of cutting room temperature on the microbiological quality of chicken breast meat
}

\author{
[Influência da temperatura da sala de cortes sobre a qualidade microbiológica da carne \\ de peito de frango] \\ A.P.R. Cintra ${ }^{1}$, M.C.G. Andrade ${ }^{1}$, M.M. Lazarini ${ }^{1}$, D.C.S. Assis ${ }^{1}$, G.R. Silva ${ }^{1}$, L.D.M. Menezes
, \\ ${ }^{1}$ Escola de Veterinária - Universidade Federal de Minas Gerais (UFMG) - Belo Horizonte, MG - Brazil \\ ${ }^{2}$ Instituto Mineiro de Agropecuária - Belo Horizonte, MG - Brazil
}

\begin{abstract}
The temperature control in the processing room is one of the major factors associated with the production of safe food with a satisfactory microbiological quality. A total of 288 samples of skinless chicken breast meat were placed in a cutting room, subjected to four different temperatures $\left(12^{\circ} \mathrm{C}, 14^{\circ} \mathrm{C}, 16^{\circ} \mathrm{C}\right.$ and $\left.18^{\circ} \mathrm{C}\right)$ and collected to evaluate the influence of the room temperature on the microbiological quality during the cutting and boning of chicken breasts. Aerobic mesophilic microorganisms were counted to evaluate the environmental contamination. In addition, coliforms at $35^{\circ} \mathrm{C}$ and $45^{\circ} \mathrm{C}$ and Staphylococcus spp. were counted, and an analysis for the presence of staphylococcal enterotoxins and Salmonella spp. was performed to determine the microbiological quality of the meat. The results showed an increase in environmental contamination $(\mathrm{P}=0.01)$ with an increase in room temperature. However, no significant differences $(\mathrm{P}>0.05)$ were observed in the meat cuts regarding the counts of coliforms at $35^{\circ} \mathrm{C}$ and $45^{\circ} \mathrm{C}$, the count of Staphylococcus spp. and the presence of Salmonella spp. Moreover, no staphylococcal enterotoxins were detected in the samples analyzed. Thus, despite increasing the environmental contamination, the increase in the cutting room temperature did not affect the microbiological quality of the final product.
\end{abstract}

Keywords: Microbiological quality, environmental contamination, chicken breast meat, cutting room temperature

\section{RESUMO}

O controle da temperatura do ambiente de processamento é um dos principais fatores relacionados à produção de alimentos seguros e com qualidade microbiológica. Com o objetivo de avaliar a influência da temperatura ambiente durante o corte e a desossa da carne de frangos sobre a qualidade microbiológica dos produtos finais, foram coletadas 288 amostras de carne de peito de frango sem pele, obtidas em uma sala de cortes climatizada submetida a quatro diferentes temperaturas ambientes $\left(12^{\circ} \mathrm{C}, 14^{\circ} \mathrm{C}, 16^{\circ} \mathrm{C}\right.$ e $\left.18^{\circ} \mathrm{C}\right)$. Para avaliação da contaminação ambiental, foi realizada a contagem de microrganismos mesófilos aeróbios e, para a avaliação da qualidade microbiológica da carne, foram realizadas a contagem de coliformes totais $e$ termotolerantes, a contagem de Staphylococcus spp., a pesquisa de enterotoxinas estafilocócicas e a pesquisa de Salmonella spp. Os resultados encontrados demonstraram um aumento da contaminação ambiental $(P=0,01)$ à medida que a temperatura da sala foi aumentada. Porém, nos cortes cárneos, não foram observadas diferenças significativas $(P>0,05)$ na contagem de coliformes totais e termotolerantes, na contagem de Staphylococcus spp. e na pesquisa de Salmonella spp. Também não foi detectada a presença de enterotoxinas estafilocócicas nas amostras analisadas. Foi concluido que, apesar da elevação da contaminação ambiental, o aumento da temperatura ambiente da sala de cortes não comprometeu a qualidade microbiológica do produto final.

Palavras-chave: qualidade microbiológica, contaminação ambiental, carne de peito de frango, temperatura da sala de cortes

Recebido em 9 de fevereiro de 2015

Aceito em 22 de dezembro de 2015

* Autor para correspondência (corresponding author)

E-mail: silvana@vet.ufmg.br 


\section{INTRODUCTION}

Chicken meat is an excellent source of protein, B-complex vitamins and minerals. Due to its intrinsic characteristics, such as its high nutrient components, high water activity and $\mathrm{pH}$ close to neutral, chicken meat also provides an excellent environment for the growth of microorganisms.

The microorganisms that contaminate chicken meat derive from the microbiota of the skin and feathers of these animals and can also originate from the nasal cavity, mouth, skin and gastrointestinal tract of the handlers. In addition, bacteria present on the surfaces of equipment, utensils and containers can be sources of food contamination. The air is another important contaminating factor because microorganismcontaining aerosols and particles are spread through the air (Jay et al., 2005; Silva Junior, 2007).

The growth of microorganisms in food depends on extrinsic and intrinsic factors; thus, a series of standards and techniques must be followed within the slaughter and processing industries of broilers to minimize contamination of the carcasses. The room in which the meat cutting is performed is one of these environments that requires monitoring, and the room temperature must be kept below $12^{\circ} \mathrm{C}$, according to Regulation (EC) 853/2004 (European Commission, 2004). The rationale for the use of lower temperatures is to reduce microbial, chemical, and enzymatic activities that can alter overall food quality because the rate of such changes is directly proportional to the temperature. Thus, the surface temperature of the meat may also favor the growth of microorganisms and affect the quality of the final product (Borges and Freitas, 2002).

There are few reports in the literature about this subject. The aim of this study was to evaluate the influence of the cutting room temperature on the microbiological quality of chicken breast meat.

\section{MATERIALS AND METHODS}

The experimental samples were collected directly from a meatpacking plant under official veterinary inspection; this plant had implemented quality control systems (Hazard Analysis and Critical Control Points - HACCP).

To perform the microbiological analyses of the meat, 288 whole broiler carcasses and 288 skinless chicken breast cuts were collected. The carcasses were collected shortly after leaving the pre-cooling area and before entering the cutting room, and the skinless chicken breast cuts were collected immediately after their production, which was performed in a processing room with a controlled temperature. The microbiological analyses of the carcasses were performed to evaluate the initial contamination and assess their uniformity.

For the analyses of the chicken breast cuts, four treatments, corresponding to the four temperatures $\left(12^{\circ} \mathrm{C}, 14^{\circ} \mathrm{C}, 16^{\circ} \mathrm{C}\right.$ and $\left.18^{\circ} \mathrm{C}\right)$ to which the cutting room was subjected were evaluated. The same cutting room was used for all treatments and samples were only collected after stabilization of the temperature according to the each treatment. Twelve replicates were used per treatment. Each work shift was considered a replicate, and each replicate consisted of a pool of six skinless chicken breast cuts, resulting in a total of 48 samples analyzed.

For the analyses of whole broiler carcasses, pools of six carcasses from each of the 48 experimental batches that went to the cutting room were used. The temperatures of the carcasses (Pectoralis major muscle) before entering the processing room and of the chicken breast collected after the cutting and boning were measured. The time between the entry of the carcasses in the processing room and obtaining the chicken breast cuts was three minutes (according to the routine in the industry); this time was similar for all of the treatments evaluated.

Throughout the experiment, the maximum and minimum temperatures of the cutting room were monitored for the different treatments and are recorded in Table 1. 
Table. 1. Mean temperatures $\left({ }^{\circ} \mathrm{C}\right)$ and standard deviations measured in the cutting and boning room for the different treatments

\begin{tabular}{ll} 
Treatments & Mean temperature $\left({ }^{\circ} \mathrm{C}\right)$ \\
\hline $12^{\circ} \mathrm{C}$ & $12.02 \pm 0.11$ \\
$14^{\circ} \mathrm{C}$ & $14.05 \pm 0.10$ \\
$16^{\circ} \mathrm{C}$ & $16.10 \pm 0.10$ \\
$18^{\circ} \mathrm{C}$ & $18.02 \pm 0.15$ \\
\hline
\end{tabular}

The environmental contamination of the airconditioned cutting room in the different treatments was assessed by counting the aerobic mesophilic microorganisms (Marshall, 1992). For these analyses, Petrifilm ${ }^{\mathrm{TM}}$ Aerobic Count (AC) plates $\left(3 \mathrm{M}^{\mathrm{TM}}\right.$, Maplewood, MN, USA) were hydrated with $1 \mathrm{~mL}$ of $0.1 \%$ saline solution and exposed in different places in the room for 15 minutes. Then, the plates were incubated at $35 \pm 1^{\circ} \mathrm{C}$ for 48 hours, after which the colonies were counted. The result was expressed in microbial density ( $\mathrm{CFU} / \mathrm{m}^{2} /$ hour), which was calculated based on the following formula:

\section{Microbial density $=$ CFU x $60 \mathrm{~min} / 15 \mathrm{~min} \mathrm{x}$ $10000 \mathrm{~cm}^{2} / 20 \mathrm{~cm}^{2}$}

The microbiological quality of the samples was evaluated by counting coliforms at $35^{\circ} \mathrm{C}$ and $45^{\circ} \mathrm{C}$, Staphylococcus aureus count, presence of staphylococcal enterotoxins and Salmonella spp.

Coliforms at $35^{\circ} \mathrm{C}$ and $45^{\circ} \mathrm{C}$ in the carcasses and chicken breast cuts (CFU.g ${ }^{-1}$ ) were counted using the Petrifilm ${ }^{\mathrm{TM}}$ EC method (Curiale et al., 1991). For these analyses, 25-g aliquots of the samples were added to $225 \mathrm{~mL}$ of $0.1 \%$ peptone salt solution and homogenized with a Stomacher (Interscience, Saint Nom La Breteche, France) for 60 seconds. The readings were performed after incubation of the plates at $35 \pm 1^{\circ} \mathrm{C}$ for 48 hours.

Staphylococcus aureus analyses were performed according to the procedures described in the Bacteriological Analytical Manual (Bennett and Lancette, 2001). For this purpose, $25 \mathrm{~g}$ of each sample were weighed, and $225 \mathrm{~mL}$ of $0.1 \%$ peptone salt solution was added. After homogenization of the samples, serial dilutions were performed and plated on Baird-Parker agar plates, which were incubated at $36 \pm 1{ }^{\circ} \mathrm{C}$ for 48 hours. The isolated colonies were inoculated into brain heart infusion (BHI) broth (Oxoid,
Hampshire, UK) and subjected to the coagulase test using rabbit plasma (Laborclin, Pinhais, PR, Brazil). In addition to the coagulase test, two complementary tests were also performed: Gram staining, to assess morphology, and the thermonuclease test using DNase Test Agar (BD, New Jersey, USA). Because no Staphylococcus aureus were detected in the analyses performed throughout the entire experiment, the results were expressed as Staphylococcus spp.

To detect the staphylococcal enterotoxins (A, B, $\mathrm{C}^{1}, \mathrm{C}^{2}, \mathrm{C}^{3}, \mathrm{D}$, and $\left.\mathrm{E}\right)$, the enzyme linked fluorescent assay (ELFA) technology associated with the VIDAS ${ }^{\text {TM}} 30$ equipment (Hennekinne et $a l ., 2007)$. For this purpose, $25 \mathrm{~g}$ of each sample were homogenized with $25 \mathrm{~mL}$ of the extraction solution (Tris buffer, 0.3M, pH 8.0) for 3 minutes to obtain a homogeneous suspension. The samples were centrifuged for 15 minutes at 3000-5000x $g$, and the supernatant was filtered. Then, $500 \mu \mathrm{L}$ of the filtrate $(\mathrm{pH} 7.5$ - 8.0) was transferred to VIDAS ${ }^{\circledR}$ Staph Enterotoxin SET2 strips. The results were read 80 minutes after inserting the strips into the equipment.

The analysis of Salmonella spp. was performed according to the AOAC International (2005). A 25 -g aliquot of each sample was added to $225 \mathrm{~mL}$ of $1 \%$ sterile peptone salt solution and incubated at $35^{\circ} \mathrm{C}$ for 24 hours. After the pre-enrichment, $100 \mu \mathrm{L}$ of the culture was transferred to Salmonella Xpress broth (bioMérieux, Hazelwood, MO, USA) and incubated at $41^{\circ} \mathrm{C}$ for 24 hours. Then, $500 \mu \mathrm{L}$ was transferred to specific strips for the detection of Salmonella spp. The strips were heated at $100^{\circ} \mathrm{C}$ for 15 minutes and placed in the VIDAS ${ }^{\text {TM} 30}$ equipment (bioMérieux, Hazelwood, MO, USA). The reading was performed after 45 minutes. The presence of Salmonella spp. was confirmed through biochemical tests using Vitek $^{\text {TM}}$ 2 equipment (bioMérieux, Hazelwood, MO, USA) (Biomeriéux, 2008).

The analyses were performed using a completely randomized design with the chicken breast cut as the covariate and the estimate of the regression models for the treatments. Four treatments, corresponding to the temperature to which the cutting room was subjected $\left(12^{\circ} \mathrm{C}, 14^{\circ} \mathrm{C}, 16^{\circ} \mathrm{C}\right.$ and $18^{\circ} \mathrm{C}$ ), were evaluated using 12 replicates of six chicken breast each. The data were transformed to evaluate the microbiological 
variables, and for those with a normal distribution (environmental contamination), Tukey's test was used with a significance level of $5 \%$. Those without a normal distribution and/or homoscedasticity were evaluated by the Kruskal-Wallis test, also with a significance level of $5 \%$. The temperature data of the carcasses and chicken breast cuts were evaluated using Tukey's test with a significance level of $5 \%$. The results for the Salmonella spp. and staphylococcal enterotoxins were subjected to descriptive analyses due to the low number of positive samples observed in the experiment.

\section{RESULTS AND DISCUSSION}

The results of coliforms at $35^{\circ} \mathrm{C}$ and $45^{\circ} \mathrm{C}$ and Staphylococcus spp. in the carcasses that were collected before entering the cutting room showed no significant differences $(\mathrm{P}>0.05)$ (Table 2). Staphylococcal enterotoxins and Salmonella spp. were also not detected.

Table 2. Results of the microbiological analyses $\left(\mathrm{CFU} \cdot \mathrm{g}^{-1}\right)$ of the carcasses collected before entering the cutting room according to the four treatments

\begin{tabular}{llllllllll}
\hline \multirow{2}{*}{$\begin{array}{l}\text { Treat- } \\
\text { ment }\end{array}$} & \multicolumn{2}{l}{ Coliforms $35^{\circ} \mathrm{C}$} & \multicolumn{3}{c}{ Coliforms $45^{\circ} \mathrm{C}$} & \multicolumn{3}{c}{ Staphylococcus spp. } \\
& Min & Max & Median & Min & Max & Median & Min & Max & Median \\
\hline $12^{\circ} \mathrm{C}$ & $<1.0 \times 10^{2}$ & $<1.0 \times 10^{2}$ & $<1.0 \times 10^{2}$ & $<1.0 \times 10^{2}$ & $<1.0 \times 10^{2}$ & $<1.0 \times 10^{2}$ & $<1.0 \times 10^{2}$ & $1.0 \times 10^{4}$ & $<1.0 \times 10^{2}$ \\
$14^{\circ} \mathrm{C}$ & $<1.0 \times 10^{2}$ & $<1.0 \times 10^{2}$ & $<1.0 \times 10^{2}$ & $<1.0 \times 10^{2}$ & $<1.0 \times 10^{2}$ & $<1.0 \times 10^{2}$ & $<1.0 \times 10^{2}$ & $7.0 \times 10^{2}$ & $<1.0 \times 10^{2}$ \\
$16^{\circ} \mathrm{C}$ & $<1.0 \times 10^{2}$ & $2.0 \times 10^{2}$ & $<1.0 \times 10^{2}$ & $<1.0 \times 10^{2}$ & $<1.0 \times 10^{2}$ & $<1.0 \times 10^{2}$ & $<1.0 \times 10^{2}$ & $3.0 \times 10^{4}$ & $2.2 \times 10^{2}$ \\
$18^{\circ} \mathrm{C}$ & $<1.0 \times 10^{2}$ & $<1.0 \times 10^{2}$ & $<1.0 \times 10^{2}$ & $<1.0 \times 10^{2}$ & $<1.0 \times 10^{2}$ & $<1.0 \times 10^{2}$ & $<1.0 \times 10^{2}$ & $5.5 \times 10^{3}$ & $<1.0 \times 10^{2}$ \\
\hline
\end{tabular}

Min = minimum; Max $=$ maximum.

The results were similar according to the Kruskal-Wallis test $(\mathrm{P}>0.05)$.

The mean results of the carcass temperatures measured before entering the cutting room are indicated in Table 3 . The carcasses fromthe 48 batches used for the experimental evaluation had similar temperatures $(\mathrm{P}>0.05)$.

Table 3. Mean temperatures $\left({ }^{\circ} \mathrm{C}\right)$ and standard deviations of the carcasses collected before entering the cutting room according to the four treatments

\begin{tabular}{ll}
\hline Treatments $^{-}$ & Carcasses $\left({ }^{\circ} \mathrm{C}\right)$ \\
\hline $12^{\circ} \mathrm{C}$ & $5.28 \pm 0.29$ \\
$14^{\circ} \mathrm{C}$ & $5.32 \pm 0.22$ \\
$16^{\circ} \mathrm{C}$ & $5.16 \pm 0.29$ \\
$18^{\circ} \mathrm{C}$ & $5.19 \pm 0.40$ \\
\hline
\end{tabular}

The means were similar according to Tukey's test $(\mathrm{P}>0.05)$. Coefficient of variation $(\mathrm{CV})=5.88 \%$.

The microbiological results of the carcasses and the assessment of their temperature showed that all of the batches used in this study had uniform conditions and were thus considered suitable for the experimental evaluation of the chicken breast cuts.
The results of the count of aerobic mesophilic microorganisms that were used to evaluate the environmental contamination of the cutting room at four different temperatures are shown in Table 4 and Figure 1. A significant difference was observed $(\mathrm{P}<0.05)$ between the microbial density and the different temperatures of the cutting room.

Table 4. Mean results of the environmental contamination analyses of the cutting room, subjected to different temperatures

\begin{tabular}{ll}
\hline Temperature $\left({ }^{\circ} \mathrm{C}\right)$ & $\begin{array}{l}\text { Microbial } \\
\left(\mathrm{CFU} / \mathrm{m}^{2} / \text { hour }\right)\end{array}$ \\
\hline $12^{\circ} \mathrm{C}$ & $2.0 \times 10^{4} \mathrm{a}$ \\
$14^{\circ} \mathrm{C}$ & $3.5 \times 10^{4} \mathrm{ab}$ \\
$16^{\circ} \mathrm{C}$ & $5.2 \times 10^{4} \mathrm{ab}$ \\
$18^{\circ} \mathrm{C}$ & $6.0 \times 10^{4} \mathrm{~b}$ \\
\hline
\end{tabular}

The means followed by different letters in the column differed significantly according to Tukey's test $(\mathrm{P}=$ 0.01 ). $\mathrm{CV}=8.0 \%$. 


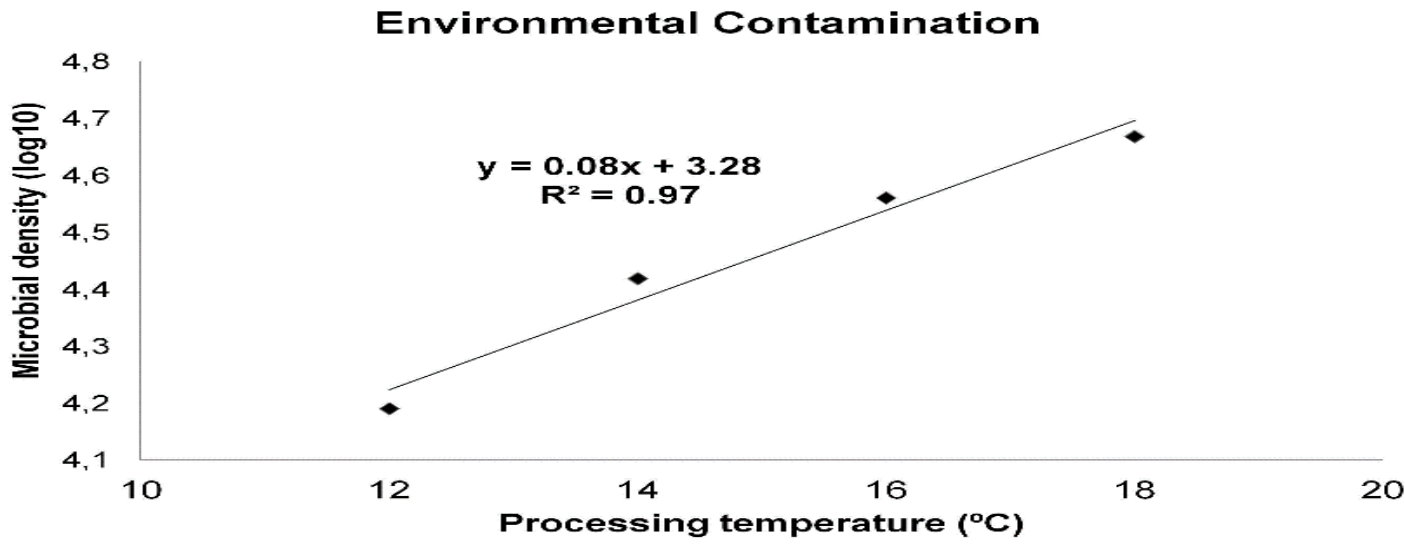

Figure 1. Linear regression plot of the environmental contamination versus the different temperatures.

The results demonstrated that an increase in temperature in the cutting room led to an increase in the count of aerobic mesophilic microorganisms in the environment. In fact, a significant difference $(\mathrm{P}=0.01)$ was observed as the cutting room temperature was increased from 12 to $18^{\circ} \mathrm{C}$. These results were expected because the conditions for the development and multiplication of aerobic mesophilic microorganisms are more appropriate at higher temperatures.

The results of the microbiological evaluation of the chicken breast cuts produced in the cutting room under different temperatures are shown in Table 5. No significant differences $(\mathrm{P}>0.05)$ were observed between coliforms at $35^{\circ} \mathrm{C}$ and $45^{\circ} \mathrm{C}$ counts and Staphylococcus spp. in the skinless chicken breast cuts.

Table 5. Results of the microbiological analyses (CFU.g ${ }^{-1}$ ) of the broiler chicken breast samples, according to the temperature of the cutting room

\begin{tabular}{llllllllll}
\hline \multirow{2}{*}{$\begin{array}{l}\text { Treat- } \\
\text { ment }\end{array}$} & \multicolumn{2}{l}{ Coliforms $35^{\circ} \mathrm{C}$} & \multicolumn{3}{l}{ Coliforms $45^{\circ} \mathrm{C}$} & \multicolumn{3}{c}{ Staphylococcus spp. } \\
\hline $12^{\circ} \mathrm{C}$ & $<1.0 \times 10^{2}$ & $3.0 \times 10^{3}$ & $1.0 \times 10^{2}$ & $<1.0 \times 10^{2}$ & $4.0 \times 10^{2}$ & $<1.0 \times 10^{2}$ & $<1.0 \times 10^{2}$ & $1.6 \times 10^{4}$ & $7.8 \times 10^{2}$ \\
$14^{\circ} \mathrm{C}$ & $<1.0 \times 10^{2}$ & $3.0 \times 10^{2}$ & $<1.0 \times 10^{2}$ & $<1.0 \times 10^{2}$ & $<1.0 \times 10^{2}$ & $<1.0 \times 10^{2}$ & $<1.0 \times 10^{2}$ & $1.6 \times 10^{4}$ & $9.0 \times 10^{2}$ \\
$16^{\circ} \mathrm{C}$ & $<1.0 \times 10^{2}$ & $5.0 \times 10^{2}$ & $1.5 \times 10^{2}$ & $<1.0 \times 10^{2}$ & $1.0 \times 10^{2}$ & $<1.0 \times 10^{2}$ & $<1.0 \times 10^{2}$ & $5.1 \times 10^{3}$ & $6.0 \times 10^{2}$ \\
$18^{\circ} \mathrm{C}$ & $<1.0 \times 10^{2}$ & $4.0 \times 10^{2}$ & $1.0 \times 10^{2}$ & $<1.0 \times 10^{2}$ & $2.0 \times 10^{2}$ & $<1.0 \times 10^{2}$ & $<1.0 \times 10^{2}$ & $5.3 \times 10^{3}$ & $2.0 \times 10^{2}$ \\
\hline
\end{tabular}

Min = minimum; $\operatorname{Max}=$ maximum.

The results were similar according to the Kruskal-Wallis test $(\mathrm{P}>0.05)$.

Low counts of coliforms at $35^{\circ} \mathrm{C}$ and $45^{\circ} \mathrm{C}$ were observed in the breast meat samples processed in the cutting room under different temperatures $\left(12^{\circ} \mathrm{C}, 14^{\circ} \mathrm{C}, 16^{\circ} \mathrm{C}\right.$ and $\left.18^{\circ} \mathrm{C}\right)$. The counts obtained met the requirements of the official inspection agencies, which stipulate a maximum value of $10^{4} \mathrm{CFU}^{-1}$ for coliforms at $45^{\circ} \mathrm{C}$ (Brazil, 2001). These microorganisms are sanitary indicators, and their presence in food suggests that other fecal pathogens may be present (Jay et al., 2005). Thus, the low incidence of these microorganisms represents a low risk of the presence of meat-contaminating pathogenic bacteria.
The counts of Staphylococcus spp. were considered low, and no staphylococcal enterotoxins (A, B, C $\mathrm{C}^{1}, \mathrm{C}^{2}, \mathrm{C}^{3}, \mathrm{D}$ and $\mathrm{E}$ ) were observed. The low counts of Staphylococcus spp. may explain the absence of staphylococcal enterotoxins in the chicken breast meat because this microorganism has the potential to produce toxins when present in levels exceeding $10^{5}$ CFU.g ${ }^{-1}$ (Valero et al., 2009). Regarding Salmonella spp., only one $(2.08 \%)$ chicken breast sample collected in the room at a temperature of $16^{\circ} \mathrm{C}$ was positive for this microorganism. 
The results of the mean temperatures of the chicken breast cuts are described in Table 6 . No significant differences $(\mathrm{P}>0.05)$ were observed in the temperature of the meat cuts between treatments.

Table 6. Mean temperatures $\left({ }^{\circ} \mathrm{C}\right)$ and standard deviations of the broiler breast cuts according to the treatments

\begin{tabular}{ll}
\hline Treatments & Chicken breast $\left({ }^{\circ} \mathrm{C}\right)$ \\
\hline $12^{\circ} \mathrm{C}$ & $5.40 \pm 0.31$ \\
$14^{\circ} \mathrm{C}$ & $5.30 \pm 0.24$ \\
$16^{\circ} \mathrm{C}$ & $5.38 \pm 0.18$ \\
$18^{\circ} \mathrm{C}$ & $5.45 \pm 0.24$
\end{tabular}

The means were similar according to Tukey's test $(\mathrm{P}<0.05) \mathrm{CV}=4.60 \%$

The time between the entry of the carcass in the cutting room and obtaining the breast cut was only three minutes. This short period can explain the consistently low temperature of the meat cuts, regardless of the variation in the room temperature.

The microbiological quality of the carcasses and chicken breast cuts reflects the efficiency of the quality control programs adopted by the company. Because of the differences in processing conditions and quality control found in slaughterhouses, further studies are needed in other processing plants to confirm or not the influence of the cutting room temperature on the microbiological quality of poultry meat.

\section{CONCLUSION}

Despite the increase in environmental microbial contamination, increasing the temperature of the cutting room did not affect the microbiological quality of the chicken breast meat.

\section{ACKNOWLEDGMENTS}

The authors thank the support of the Colegiado de Pós-Graduação em Ciência Animal of the Escola de Veterinária at the Universidade Federal de Minas Gerais - UFMG (Belo Horizonte, Minas Gerais, Brazil) and the PróReitoria de Pesquisa at the UFMG (Belo Horizonte, Minas Gerais, Brazil) for providing funds for this research and resources for publication. The authors also thank the Conselho Nacional de Desenvolvimento Científico e
Tecnológico - CNPq (Brasília, Federal District, Brazil) for providing scholarships, the Instituto Mineiro de Agropecuária - IMA (Belo Horizonte, Minas Gerais, Brazil) for facilitating the microbiological analyses and the Avivar Alimentos S/A (São Sebastião do Oeste, Minas Gerais, Brazil).

\section{REFERENCES}

BENNETT, R.W.; LANCETTE, G.A. bacteriological analytical manual: Staphylococcus aureus. 2001. Available: $<$ http://www.fda.gov/Food/FoodScienceResearch /LaboratoryMethods/ucm071429.htm>

Accessed: 27 October 2014.

BIOMERIÉUX. Vitek 2 - Technology, 398, p.510773 - 5PT1, 2008.

BORGES, J.T.S.; FREITAS, S. Aplicação do Sistema Hazard Analysis and Critical Control Points (HACCP) no processamento de carne bovina fresca. Bol. CEPPA, v.20, p.1, 2002.

BRASIL. Ministério da Saúde. Agência Nacional de Vigilância Sanitária. 2001. Resolução RDC n ${ }^{\circ}$ 12. Aprova o Regulamento técnico sobre padrões microbiológicos para alimentos. Diário Oficial da União, Brasília, n.7, 10 de janeiro de 2001. Seção 1, p.45-53.

CURIALE, M.; SONS, T.; MCIVER, D. et al. Dry rehydratable film for enumeration of coliforms at $35^{\circ} \mathrm{C}$ and Escherichia coli in foods: collaborative study. J. Assoc. Oil Anal. Chem. Int., v.74, p.635-648, 1991.

EUROPEAN COMMISSION. Regulation (EC) No. 853/2004 of the European Parliament and of the Council laying down specific hygiene rules for the hygiene of foodstuffs. Off. J. Europ. Union, L139, 2004.

HENNEKINNE, J.; GUILLIER, F.; PERELLE, $\mathrm{S}$. et al. Intralaboratory validation according to the EN ISO 16140 standard of the Vidas SET2 detection kit for use in official controls of staphylococcal enterotoxins in milk products. $J$. Appl. Microbiol., v.102, p.1261-1272, 2007.

JAY, J.M.; LOESSNER, M.J.; GOLDEN, D.A. Modern food microbiology. New York: Springer, 2005. 
MARSHALL, R.T. Standard methods for the examination of dairy products. 16.ed. Washington, DC: American Public Health Association, 1992.

SALMONELLA in foods, enzyme-linked immunofluorescent assay screening method (VIDAS Salmonella [SLM] Assay (bioMerieux Vitek, SA, 595 Anglum Drive, Hazelwood, MO 63042, USA). 18.ed. Gaithersburg: AOAC International. 2005. p.139-141. (AOAC Official Method 996.08).
SILVA JUNIOR, E.A. Manual de controle higiênico-sanitário em serviços de alimentação. 6.ed. São Paulo: Varela, 2007.

VALERO, A.; PEREZ-RODRIGUEZ, F.; CARRASCO, E. et al. Modelling the growth boundaries of Staphylococcus aureus: Effect of temperature, $\mathrm{pH}$ and water activity. Int. J. Food Microbiol., v.133, p.186-194, 2009. 